\title{
レター
}

\section{Spatial Distribution of Atomic Vapor of Alkaline Earth Elements around a Tantalum-filament Atomizer}

\author{
Masaaki YanagisawA*, Seikoh YokoYama**, \\ and Kuniyuki KITAGAWA** \\ * Present address: Research \& Development Laboratory, Japan Fine Ceramics \\ Center, Mutsuno, Atsuta, Nagoya 456 Japan \\ ** Department of Applied Chemistry, School of Engineering, Nagoya University, \\ Furo-cho, Chikusa, Nagoya 464-01 Japan
}

(Received November 4, 1992)

\author{
柳 沢 雅明*・横山精 光**・北川邦行** \\ * 現住所： (財) ファインセラミックスセンター試験研究所 名古屋
市熱田区六野 $2-4-1 \overline{\bar{T}} 456$
** 名古屋大学工学部応用化学科 名古屋市千種区不老町 $\bar{T} 464-01$
}

(1992 年 11 月 4 日受理)

\begin{abstract}
Spatial distributions of atomic vapors of alkaline earth elements around a tantalumfilament atomizer were studied in conjunction with the dissociation energy of diatomic oxide molecules. The spatial distributions of atoms in $\mathrm{Ar}$ atmosphere were narrower in the order which was coincident with the order of dissociation energy of oxide in magnitude. The presence of hydrogen (ca. 1\%) in the purge gas expanded significantly the narrow distributions.
\end{abstract}

\section{Introduction}

Electrothermal atomizers (ETA's), using a non-tubular heating element such as a carbon filament ${ }^{1)}$, a glassy carbon strip $^{2)}$ or a metal boat $^{3)}$ have an advantage in atomic absorption spectrometry (AAS); such a nonatomic species as fume which is evolved from sample matrices during a charring process is rapidly purged out of the light beam. Concurrently, background absorption caused by non-atomic species can be minimized on the subsequent atomization process. A commercially available metal-boat atomizer has been applied to practical analysis ${ }^{3)}$. Compared with ETA's using a tubular heating element such as a graphite tube furnace, those using a non-tubular heating element have such a problem that more serious chemical interference can be caused by sample matrices, which may be associated with atomization process in thermal non-equilibrium. Another serious problem lies in a narrow spatial distribution of atomic vapor around a heating element. The sensitivity becomes significantly low with the wide beam diameter $(4-6 \mathrm{~mm})$ of a conventional hollow cathode lamp, since a large part of the source radiation undergoes no absorption. Narrowing the beam in order to gain a higher sensitivity would result in lowering the signal-to-noise ratio $(\mathrm{S} / \mathrm{N})$, particularly for the source lines of 
low emission energy.

Agget and West have studied spatial distributions of atomic vapors above a carbonfilament ETA for volatile elements such as $\mathrm{Cd}, \mathrm{Ag}, \mathrm{Pb}$ and $\mathrm{Cu}^{1}$. The atomic vapors of these volatile elements were distributed over a relatively wide space above the filament. In this study, narrow spatial distributions of atomic vapors around a Tafilament atomizer were found for alkaline earth elements, $\mathrm{Ca}, \mathrm{Sr}$ and $\mathrm{Ba}$. The narrow spatial distributions were studied in conjunction with the dissociation energy of diatomic molecules such as metal monoxides and monochlorides. An attempt to expand the narrow spatial distribution of atoms was also successfully made with the aid of the reductive power of hydrogen contained at a low concentration (ca. 1\%) in an $\mathrm{Ar}$ purge gas.

\section{Experimental}

The ETA assembly used in this experiment was basically the same as that constructed for a previous study ${ }^{2}$. In a Pylex glass dome with quartz windows for AAS measurements, a Ta-filament of $0.5 \mathrm{~mm}$ in diameter, as a heating element, was fitted on stainless steel electrodes. The Ta-filament had a overall length of $50 \mathrm{~mm}$, and a hill of $4 \mathrm{~mm}$ in height and $5 \mathrm{~mm}$ in length. The hill top has a depression of $0.25 \mathrm{~mm}$ for sample holding. On both sides ca. $1 \mathrm{~mm}$ apart from the Ta-filament, horizontal slits of $1 \mathrm{~mm}$ in width were mounted in order to narrow the source light beam. The electrodes were mounted on a stage which was movable vertically at a pitch of $0.25 \mathrm{~mm}$. Thus, the vertical distribution of atomic vapor around (above and below) the Ta-filament was observed through AAS measurements.

Argon or hydrogen-containing argon was used as a purge gas. The flow rates of Ar and $\mathrm{H}_{2}$ were regulated at $2.21 / \mathrm{min}$ and $21 \mathrm{ml} / \mathrm{min}$, respectively. An aliquot $(1 \mu \mathrm{l})$ of a sample solution was taken onto the filament depression, dried by passing a low current through the filament and atomized at a high current. The temperature of the Ta-filament was measured by means of an optical pyrometer (Yokogawa Elec. Co.). A Nippon Jarrell-Ash AA-1E spectrometer equipped with a Hitachi strip chart recorder QPD-54 was used for AAS measurements. The atomic lines used for AAS measurements were Ca (I) $422.7 \mathrm{~nm}$, Sr (I) $460.7 \mathrm{~nm}$ and $\mathrm{Ba}$ (I) $553.5 \mathrm{~nm}$. Different salts such as chlorides, acetates and perchlorates of $\mathrm{Ca}, \mathrm{Sr}$ and $\mathrm{Ba}$ were used for the test samples.

\section{Results and discussion}

Figure 1 shows the spatial distribution profiles of relative peak absorbance (as for the definition, refer to the figure caption) around the Ta-filament for $\mathrm{Ca}, \mathrm{Sr}$ and $\mathrm{Ba}$. The absorbance substantially reflects the number of atoms in the light beam, though

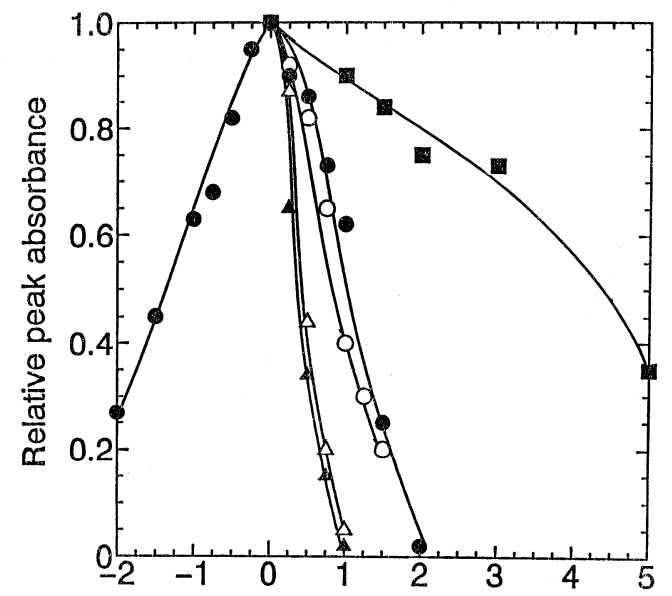

Height above Ta-filament atomizer $(\mathrm{mm})$

Fig. 1. Spatial distribution of relative absorbance for alkaline earth elements around the Ta-filament. The abscissa is the height above the Ta-filament, where the bottom of the source light beam passes. The ordinate is the relative absorbance with respect to the absorbance at the $0 \mathrm{~mm}$ height $\left(\mathrm{A}_{\mathrm{o}}\right)$. The purge gas is $\mathrm{Ar}$ at $2.2 \mathrm{1} / \mathrm{min}$, except for - $\triangle, \mathrm{Ba} 104 \mathrm{ng}$ as $\mathrm{BaCl}_{2}\left(\mathrm{~A}_{\mathrm{o}}=0.13, \mathrm{~T}=\right.$ $2030^{\circ} \mathrm{C}$; $\mathbf{\Delta}$, Ba $102 \mathrm{ng}$ as $\mathrm{Ba}\left(\mathrm{CH}_{3} \mathrm{COO}\right)_{2}$ $\left(\mathrm{A}_{\mathrm{o}}=0.34, \mathrm{~T}=1950^{\circ} \mathrm{C}\right) ; \mathrm{O}$, Ca $1 \mathrm{ng}$ as $\mathrm{CaCl}_{2}\left(\mathrm{~A}_{\mathrm{o}}=0.11, \mathrm{~T}=2050^{\circ} \mathrm{C}\right) ; \bullet, \mathrm{Sr} 2 \mathrm{ng}$ as $\mathrm{SrCl}_{2}\left(\mathrm{~A}_{\mathrm{o}}=0.24, \mathrm{~T}=1840^{\circ} \mathrm{C}\right) ; \mathbf{\mathrm { a }}, \mathrm{Ca}$ $102 \mathrm{ng}$ as $\mathrm{Ca}\left(\mathrm{ClO}_{4}\right)_{2}\left(\mathrm{~A}_{\mathrm{o}}=0.21, \mathrm{~T}=1630^{\circ} \mathrm{C}\right.$, Ar $2.21 / \mathrm{min}+\mathrm{H}_{2} 21 \mathrm{ml} / \mathrm{min}$ ). 
in order to obtain more exact results, a correction is necessary with respect to its dependence on the gas temperature, i.e. the Doppler effect.

The spatial distribution profile of $\mathrm{Sr}$ indicates that $\mathrm{Sr}$ atoms populate almost symmetrically below and above the Ta-filament. This suggests that the atomic clouds are not seriously perturbed by a purge gas flow or convection currents around the Ta-filament. Figure 1 also illustrates that the distributions of $\mathrm{Ba}, \mathrm{Ca}$ and $\mathrm{Sr}$ atoms are narrower in that order. Among the important factors associated with the difference in the spatial distribution of atoms are the diffusion coefficient of species in Ar, and the rates of reactions such as dissociation from diatomic molecules to atoms and their recombination. The diffusion processes were theoretically estimated to affect less significantly the difference in the spatial distribution : the peak absorbance is approximately inversely proportional to the 4 th root of the reduced mass of the analyte species and Ar. The following reactions are deduced to be mainly associated with the difference in the spatial distribution of atoms. In the course of the temperature rise of the Tafilament, the analyte salts, dichlorides and oxygen-containing compounds (nitrate, perchlorates and acetate) may be rapidly decomposed into monochlorides and monoxides on the Ta-filament, respectively. Parts of them, particularly monochlorides with high vapor pressure diffuse around the Ta-filament and undergo thermal dissociation into atoms and also recombination with $\mathrm{Cl}$ atoms or oxygen atoms of impurities such as $\mathrm{H}_{2} \mathrm{O}$ and $\mathrm{CO}_{2}$ in $\mathrm{Ar}$.

Most of monoxides may dissociate into atoms on the Ta-filament. The resulting atoms, during diffusing apart from the Tafilament, also may undergo recombination. The recombined atoms can again thermally dissociate. Since the recombination reactions are very rapid, the slow dissociation reactions are most likely the rate-determining steps. For the simple thermal dissociation of diatomic molecules, the activation energy approximates to the dissociation energy. Hence, the diatomic molecules with a higher dissociation energy are decomposed more slowly, leading to a lower population of atoms. Such a tendency may be more notable at a spatial point more distant from the Ta-filament, where the gas temperature becomes lower. Hence, the spatial distribution can be narrower for the element, the dissociation energy of the diatomic molecules of which is higher.

The dissociation energy is $<2.76 \mathrm{eV}$ for $\mathrm{CaCl}, 4.3 \mathrm{eV}$ for $\mathrm{SrCl}, 5.0 \mathrm{eV}$ for $\mathrm{BaCl}, 4.3 \mathrm{eV}$ for $\mathrm{CaO}, 4.2 \mathrm{eV}$ for $\mathrm{SrO}$ and $5.75 \mathrm{eV}$ for $\mathrm{BaO}^{4}$ ) (or $5.0 \mathrm{eV}$ for $\mathrm{CaO}, 4.8 \mathrm{eV}$ for $\mathrm{SrO}$ and $5.9 \mathrm{eV}$ for $\mathrm{BaO}^{5)}$ ). Thus, the dissociation energies of $\mathrm{Ba}, \mathrm{Sr}$ and $\mathrm{Ca}$ monochlorides are higher in that order. On the other hand, the dissociation energies of monoxides are higher in different order $\left(\mathrm{D}_{\mathrm{BaO}}>\mathrm{D}_{\mathrm{CaO}}>\right.$ $\left.\mathrm{D}_{\mathrm{sro}}\right)$. As described above, the spatial distributions of $\mathrm{Ba}, \mathrm{Ca}$ and $\mathrm{Sr}$ atoms are narrower in that order. Accordingly, monoxides are the species which exist more likely around the Ta-filament at a high temperature than monochlorides. Figure 1 also shows that the spatial distribution profile of $\mathrm{Ba}$ for $\mathrm{BaCl}_{2}$ is almost the same as that for $\mathrm{Ba}\left(\mathrm{CH}_{3} \mathrm{COO}\right)_{2}$ from which $\mathrm{BaO}$ may be mostly produced on the thermal decomposition. The monochlorides, $\mathrm{BaCl}$ produced on the Ta-filament may be immediately converted into $\mathrm{BaO}$ through a reaction with oxygen atoms of impurities contained in the purge gas.

As seen from Fig. 1, the spatial distribution profile spreads over a wide space in an $\mathrm{Ar}-\mathrm{H}_{2}$ purge gas, in spite of a lower temperature of the Ta-filament and an oxidative salt, perchlorates used as the analyte. The reductive power of hydrogen greatly contributes to making a higher degree of atomization of the analyte on the Ta-filament and also to preventing the resulting atoms from being recombined with the oxygen atoms of the impurities in the purge gas. Thus, hydrogen at a low concentration of ca. $1 \%$ in the Ar purge gas expanded the spatial distribution notably. Such an effect would be also useful in minimizing matrix effects encountered for the electrothermal atomizers using a nontubular heating element, as well as in increasing the 
sensitivity.

\section{Acknowledgment}

The authors wish to thank Mr. T. Imura, Mr. T. Watanabe and Mr. S. Takahashi for elaborate manufacturing.

\section{References}

1) J. Agget and T.S. West: Anal. Chim. Acta, 57, 15 (1971).
2) M. Yanagisawa and T. Takeuchi: Bunseki Kagaku, 23, 364 (1974).

3) N. Fudagawa and A. Hiroki: Bunseki Kagaku, 36, T85 (1987).

4) A. G. Gaydon: Dissociation Energies and Spectra of Diatomic Molecules 3rd Ed., (London, Chapman and Hill, 1968) p. 263 and 285 .

5) B. V. L'vov: Atomic Absorption Spectroscopy, (Jerusalem, Israel Program for Scientific Translations, 1969) p. 115. 
賛助会 員 名簿

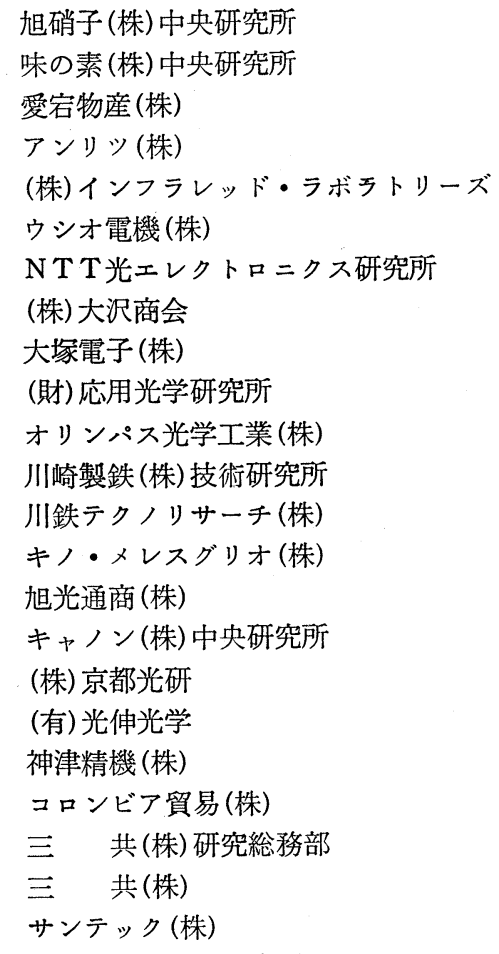

塩野義製薬 (株) 研究所

(株) 資生堂研究所

(株) 島津製作所

ジャスコインターナショナル(株)

信越化学工業 (株)

新日本製鉄 (株) 先端技術研究所

住友化学工業 (株) 有機合成研究所

セイコー電子工業 (株)

西進商事 (株)

西進商事 (株) 東京支店

清和陶器 (株)

セキテクノトロン(株)

竹田理化工業 (株)

大機ゴム工業(株)

T D K (株) 開発研究所

テルモ (株) 研究開発センター

東然 (株) 総合研究所

(株) 東京インスッルメンツ

(株) 東芝

東北電子産業 (株)

東ソー (秼)

東洋ハイブリッド(株)
(株)トプュン

(株) 東レリサーチセンター 中野電子工業 (株)

(株) ニコン

日産自動車 (株) 総合研究所

日製産業(株)

日本板硝子 (株) 中央研究所

日本科学エンジニアリング (株)

日本鋼管 (株) 技術研究所

日本ジャーレル・アッシュ(株)

日本真空光学 (株)

日本石油 (株) 中央技術研究所

日本電子 (株)

日本電子輸入販売 (株)

日本パーカーライジング (株) 総合技術研究所

日本パステック (株)

日本ブルカー (株)

日本分光 (株)

日本治金工業(株)川崎製造所

(株) ハイテクノロジー

(株) パーキンエルマージャパン

浜松ホトニックス (株)

(株) 日立製作所

(株) 日立製作所計測器事業部

富士光機 (株)

富士写真フィルム (株)

富士ゼロックス(株)

(株)富士通研究所

分光計器 (株)

ヘルッ工業(株)

H O Y A (株)

(株)堀場製作所

松下電器産業(株)

松下電子工業(株)

丸文(株)

(株) 溝尻光学工業所

三井東圧化学 (株) 中央研究所

三菱電機 (株) 中央研究所

ミノルタカメラ (株)

(株) 村田製作所

(株)ルミネックス

(株)メステック

理学電機工業(株)

(株) リガク光事業部

平成 5 年 1 月 26 日現在の本学会賛助会員は上記のと括りです。本学会の事業に対し御賛助いただき 厚く御礼申し上げます。（五十音順） 